ISSN 1991- 8690

Website: http://jsci.utq.edu.iq

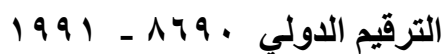

Email: utjsci@utq.edu.iq

\title{
Isolation and identification of resistance Staphylococcus aureus to vancomycin \& Methicillin from outpatients clinic in AL-Shefa General Hospital in Basrah district
}

\author{
R.M.M.AL-Mosawi \\ Department of Biology- College of Science- University of Basrah-Iraq
}

\begin{abstract}
$\underline{\text { Abstract }}$
Research doing on isolation and identification of S.aureus resistance to vancomycin and Methicillin on 547 samples outpatient ( adults and non -adults) clinic of Al Shefa General Hospital in Basrah district during the period from October, 2007 to March, 2008, their age was ranged from 5-65 years.

One urine sample was collected from each patient under investigation and cultured by the streaking method onto Enrichment media and Selective (differential) media because of the common urinary pathogens and other pathogens grow well on these cultures media.

For isolation species depending to genus staphylococcus especially S.aureus (COPS) and (CONS); the samples urine streaking on Mannitol-Salt agar (selective media), the biochemical reactions (identification tests) were doing for staphylococcus Spp. especially COPS, CONS and other bacterial species in dependence on Bergey's Manual of Determinative Bacteriology (Holt et.al., 1994).

Furthermore, two antimicrobial agents were used in this research : Vancomycin in (30 $\mathrm{mg}$ ) and methicillin ( $5 \mathrm{mg}$ ) for antimicrobial susceptibility test to S.aureus bacterial isolates (COPS); (CONS).

Results showed that the highest isolation rate of infection with S.aureus in cases: VRSA,VISA and VSSA were correlated with age group above 50 years in proportion: $7.93 \%$, $4.76 \%$ and $12.69 \%$ respectively. Also, the Methicillin Resistance Staphylococcus aureus (MRSA) was recovered $6.42 \%$ and $9.52 \%$ in age groups above 50 years. The MR Staphylococci (CONS) was isolated in this study in proportion $4.76 \%$.

Besides, different species of bacterial isolates other than S.aureus were identified in 55 infected person with UTI by the common diagnosis method. They consisted of E.coli $(38.18 \%)$ as the most common bacterium, P.aeruginosa $(29.09 \%)$, K. pneumoniae $(21.81 \%)$ and E.faecalis $(10.90 \%)$.
\end{abstract}




\section{$\underline{\text { Introduction }}$}

A urinary tract infection ( UTI) is a condition where one or more structures in the urinary tract become infected after bacteria overcome its strong natural defenses [1]. In spite of these defenses, UTIs are the most common of all infections and can occur at any time in the life of an individual [2-3]. Almost $95 \%$ of cases of UTIs are caused by bacteria that typically multiply at the opening of the urethra and travel up to the bladder ( Known as the ascending route) [2]. Much less often, bacteria spread to the kidney from the bloodstream [4]. Normal urine is sterile [5]. It contains fluids, salts, and waste products, but it is free from bacteria, viruses and fungi [5]. An infection occurs when microorganisms, usually bacteria from the digestive tract, cling to the opening of the urethra and begin to multiply $[6-7,8]$.

Staphylococci are GramPositive spherical or cocci bacteria that occur in microscopic clusters resembling grapes. Bacteriological culture of the nose and skin of normal humans invariable yields Staphylococci. In 1884, Rosenbach described the two pigmented colony types of Staphylococci and proposed the appropriate nomenclature: Staphylococcus aureus (Yellow) and S. albus (white), the latter species is now named S.epidermidis [9]. Taxonomically, the genus Staphylococcus is in the bacterial family Staphylococcaceae, which includes three lesser known genera, Gamella, Macrococcus and Salinicoccus [10-11]. The Staphylococci are spherical, nonmotile, non- sporogenous bacteria, occurring singly, in pairs, in tetrads and in irregular clusters (from which they derive their genus name) [10]. They are facultative anaerobes that grow by aerobic respiration and by fermentation that yields principally lactic acid.

Many strains produce orange or yellow, white pigments which have traditionally been associated with but are not definitive of the genus or species. The Coagulase- positive strains produce a variety of toxins (acquired resistance to practically all antibiotics) and the genus as a whole is potentially pathogenic [10-13].

AROs are bacteria that resist the effects of antibiotics. Bacteria possess a remarkable number of genetic mechanisms for resistance to antibiotics [14-15].

MRSA: Staphylococcus aureus is a species of bacteria normally found in the nares and on the skin. It is commonly known as an apportunistic pathogen. This means that normally it does not cause disease, but may cause disease given the apportunity to invade the human host [16]. Furthermore, the emergence of vancomycin resistance in $S$. aureus has been anticipated [12].

I have done this research because, the fewer researches and information in Basrah University about this subject (aim study)

\section{Materials and Methods}

Study population: The population under study was among people attending to the outpatient clinic of Al-Shefa General Hospital. A total number of five hundred and seventy four people (547) were investigated, their age ranged from 5 to 65 years, the investigation period extended from October, 2007 to March, 2008. 
Sample collection and method culture: Urine samples were collected in a sterile container from each people and transported to the laboratory for cultured by the streaking method on MacConkey and blood agar. Streaking samples on Blood agar for microbes activation then cultured on Mannitol -Salt agar by such method for the members of staphylococci groups, then incubated at $35-37 C^{o}$ for $24-48$ hrs. after that sub cultured on Nutrient agar for each isolates $[11,17]$.

The media used in this research were prepared following the instructions of the manufacturers and using sterile laminar flow cabinet experiments has done, which present in microbiological laboratory ( $\mathrm{Lab}$ ) for postgraduate in biology department and microbiological Lab in Al- Shefa General Hospital.

1 In laboratory diagnosis the General Urine Examination ( GUE) have been done [18], to detect the color , turbidity, acidity, albumin content , Sugar content and microscopic examination. Furthermore, we made primary diagnostic tests include: Gram's stain, Oxidase test, Catalase test,
Oxidation / fermentation test and mortality tests $[11,17,19]$. Finally, the identification tests of Staphylococcus Spp. especially COPS, CONS and other bacteria were applied according to Bergey's Manual of Determinative Bacteriology, 994, [10].

Antimicrobial Susceptibility Test: The determination of bacterial susceptibility of different isolates of S.aureus to two antimicrobial agents (Methicillin and Vancomycin) in the present work was made by using Disc plate method according to Weckbach and Langlois, 1976 [20], by putting 0.1 $\mathrm{ml}$ of a young culture $18 \mathrm{hrs}$. grown in $1.5 \mathrm{ml}$ from Nutrient broth (Oxoid) in Mueller-Hinton agar ( MHA) plates and spreading onto surface of the medium with a sterile glass rod ( L-Shape) then, the appropriate discs were placed on the agar ( MHA) with flamed forceps and gently pressed down to ensure contact, plates were incubated at $37 \mathrm{C}^{\circ}$ for $48 \mathrm{hrs}$. Finally, the diameters of inhibition zones were measured by using a ruler and the sizes of the zones inhibition were then interpreted by referring to standard Table (1-a,b).

Table (1,a) Diameter of zones inhibition

\begin{tabular}{|c|c|c|c|c|}
\hline \multirow[t]{2}{*}{ Antibiotic } & \multirow{2}{*}{$\begin{array}{l}\text { Disc } \\
\text { concentration }\end{array}$} & \multicolumn{3}{|c|}{$\begin{array}{l}\text { Diameter ( Millimeters ) of zones } \\
\text { inhibition }\end{array}$} \\
\hline & & Resistant & Intermediate & Susceptible \\
\hline Vancomycin & $30 \mathrm{mcg}$ & 9 or less & $10-11$ & 12 or more \\
\hline $\begin{array}{l}\text { Methicillin (Penicillinase } \\
\text { resistant penicillin class) }\end{array}$ & $5 \mathrm{mcg}$ & $<10$ & $10-13$ & $>13$ \\
\hline
\end{tabular}

Bauer et.al., 1966, [14]. 


\section{Table $(1, b)$ Size of zones of inhibition}

\begin{tabular}{|c|c|c|c|c|c|}
\hline Antibiotic & Concentration & $\begin{array}{c}\text { Bacterial } \\
\text { species }\end{array}$ & $\begin{array}{l}\text { Diameter } \\
\text { of zones }\end{array}$ & $\begin{array}{l}\text { No. of } \\
\text { isolates }\end{array}$ & Result \\
\hline $\begin{array}{c}\text { Vancomycin } \\
\text { (VA) }\end{array}$ & $30 \mathrm{mcg}$ & $\begin{array}{c}\text { COPS } \\
\text { (S.aureus) } \\
\\
\text { CONS } \\
\text { Staphylococcus } \\
\text { spp }\end{array}$ & $\begin{array}{c}8-9 \mathrm{~mm} \\
10-11 \mathrm{~mm} \\
12-14 \mathrm{~mm} \\
11 \mathrm{~mm}\end{array}$ & $\begin{array}{c}10 \\
7 \\
22 \\
4\end{array}$ & $\begin{array}{c}\text { VRSA } \\
\text { VISA } \\
\text { VSSA } \\
\text { VICONS }\end{array}$ \\
\hline $\begin{array}{l}\text { Methicillin } \\
\text { (ME) }\end{array}$ & $5 \mathrm{mcg}$ & $\begin{array}{c}\text { COPS } \\
\text { (S.aureus) } \\
\text { CONS } \\
\text { Staphylococcus } \\
\text { spp }\end{array}$ & $\begin{array}{c}9 \mathrm{~mm} \\
11-12 \mathrm{~mm} \\
14-15 \mathrm{~mm} \\
8-9 \mathrm{~mm}\end{array}$ & $\begin{array}{c}25 \\
11 \\
3 \\
3\end{array}$ & $\begin{array}{c}\text { MRSA } \\
\text { MISA } \\
\text { MSSA } \\
\text { MRCONS }\end{array}$ \\
\hline
\end{tabular}

My results according to Bauer et.al.,(1966).

\section{$\underline{\text { Results }}$}

Table (2) : Shows, the occurrence of UTI in patients depending on sex.( 101 patients $1547,18.46 \%$ ) were proved to be infected with urinary tract infection ( UTI). 32 patients were males ( $14.95 \%$ ) and 69 females $(20.72 \%)$.

The patients under study were divided into six age groups(5-14, 15-24,25-34,35-44,45-54 and 55-65), as shown in Table (3). It is evident that the highest isolation rate of infection with $S$. aureus in any case; (VRSA, VISA and VSSA) occurred in ages above 50 years in all patients, which correspond to 2.14 $\%, 7.93 \%$ in patient ( +ve VRSA) while, represents $2.14 \%, 4.76 \%$ in patients ( +ve VISA) and in (+ve VSSA) patients represented $4.28 \%$ and $12.69 \%$.

Data present in ( Table 4) revealed that the highest isolation rate of infection with $S$. aureus ( +ve MRSA) associated with patient in age groups 45-54 and 55-
65 years which recovered $6.42 \%, 9.52 \%$ whereas, in patients (+ve MISA) tend to be frequently distributed only in age group 45$54 ; 3.57 \%$.Besides, in patients (+ve MSSA) tends to be frequently distributed in age group 55-65 years and correspond to $3.17 \%$.

Concerning Table (5) it shows that, a high rate of infection with MRStaphylococci ( CONS) correlated with patients in age group 55-65 years which correspond to $4.76 \%$.

Table (6) shows, several bacterial species other than $S$. aureus were isolated from patient's UTI, they consisted of E.coli which was the most frequently isolated bacterial species $38.18 \%$ followed by $P$. aeruginosa $29.09 \%$, K. pneumonia $21.81 \%$ and E.faecalis $10.90 \%$. 
The antimicrobial susceptibility for vancomycin \& methicillin were ascertained when, the diameters of inhibition zones measured by a ruler and the sizes of the zones of inhibition were then interpreted by referring to standard Bauer et.al., 1966,[14]. (Table 1-a,b) and ( Fig. 1-3).

\begin{tabular}{||l||c||c||}
\hline \multicolumn{2}{|c|}{ Table (2) Distribution of UTI according to sex. } \\
\hline \multicolumn{1}{|c||}{ Sex } & No. of tested Patient & $\begin{array}{c}\text { No. of Patient UTI } \\
\text { and percentage }\end{array}$ \\
\hline \hline Male & 214 & $32(14.95)$ \\
\hline Female & 333 & $69(20.72)$ \\
\hline Total & 547 & $101(18.46)$ \\
\hline
\end{tabular}

Table (3) Distribution of Patients with Vacomycin Susceptibility according to age

\begin{tabular}{|c|c|c|c|c|}
\hline Age year & $\begin{array}{c}N_{0} \text { of tested } \\
\text { patient }\end{array}$ & $\begin{array}{c}\mathrm{N}_{0} \text {, and }(\%) \text { of } \\
\text { patient +ve } \\
\text { in VSSA }\end{array}$ & $\begin{array}{c}\mathrm{N}_{0} \text {, and }(\%) \text { of } \\
\text { patient +ve } \\
\text { in VISA }\end{array}$ & $\begin{array}{c}\mathrm{N}_{0} \text {, and }(\%) \text { of } \\
\text { patient +ve in } \\
\text { VRSA }\end{array}$ \\
\hline $5-14$ & 48 & 0 & 0 & 0 \\
\hline $15-24$ & 81 & $1(1.23)$ & 0 & 0 \\
\hline $25-34$ & 96 & $3(3.12)$ & 0 & $2(2.08)$ \\
\hline $35-44$ & 119 & $4(3.36)$ & $1(0.84)$ & 0 \\
\hline $45-54$ & 140 & $6(4.28)$ & $3(2.14)$ & $3(2.14)$ \\
\hline $55-65$ & 63 & $8(12.69)$ & $3(4.76)$ & $5(7.93)$ \\
\hline Total & 547 & $22(21.78)$ & $7(6.93)$ & $10(9.90)$ \\
\hline
\end{tabular}




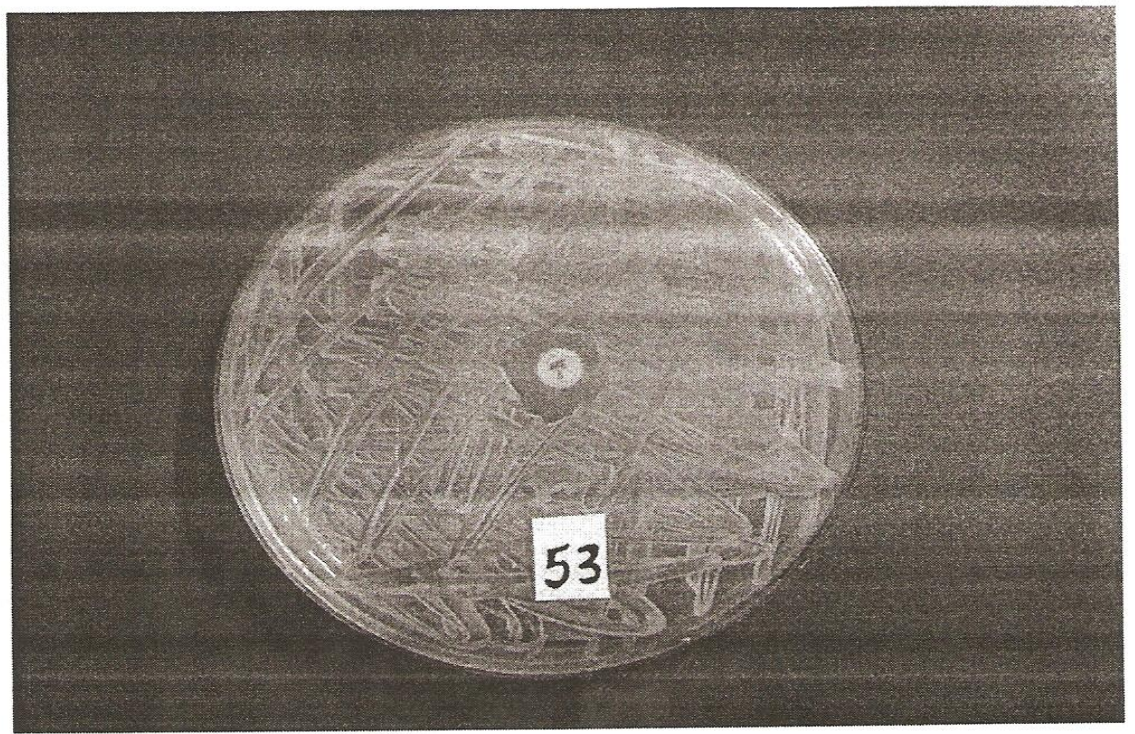

Figure (1)

The susceptibility to methicillin:

Isolate number 53 susceptible to methicillin with inhibition zone correspond to $16 \mathrm{~mm}$

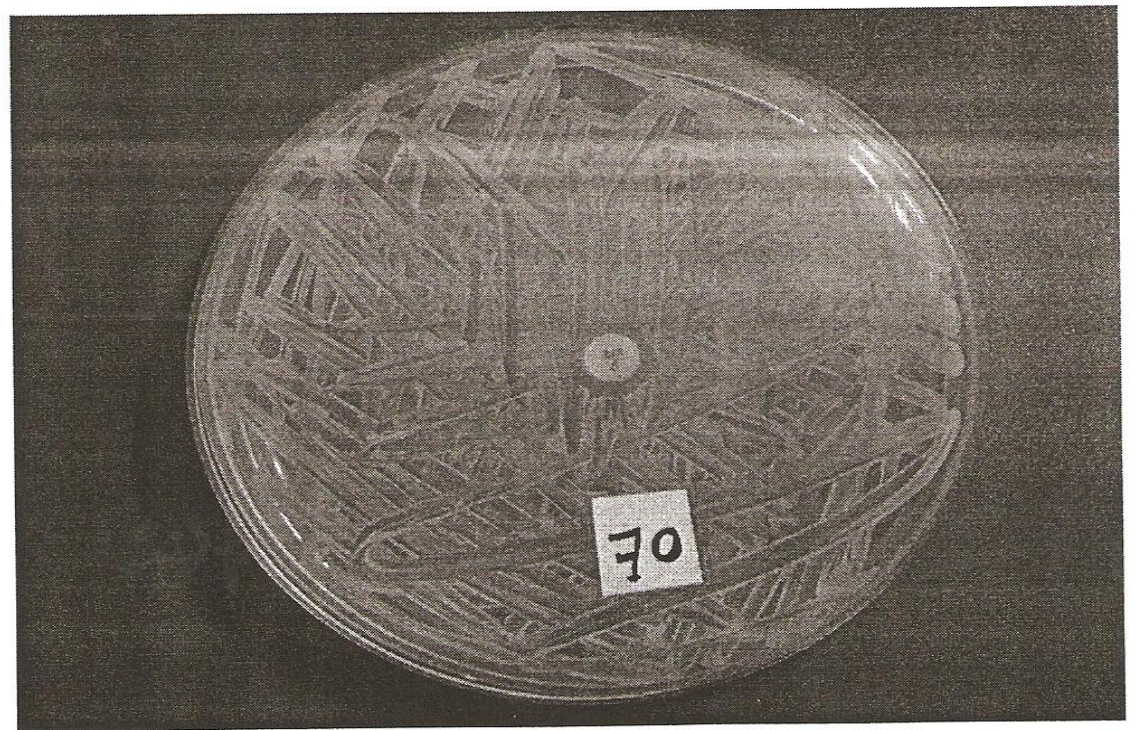

Figure (2)

The susceptibility to methicillin:

Isolate number 70 resistant to methicillin with inhibition zone correspond to $4 \mathrm{~mm}$ 


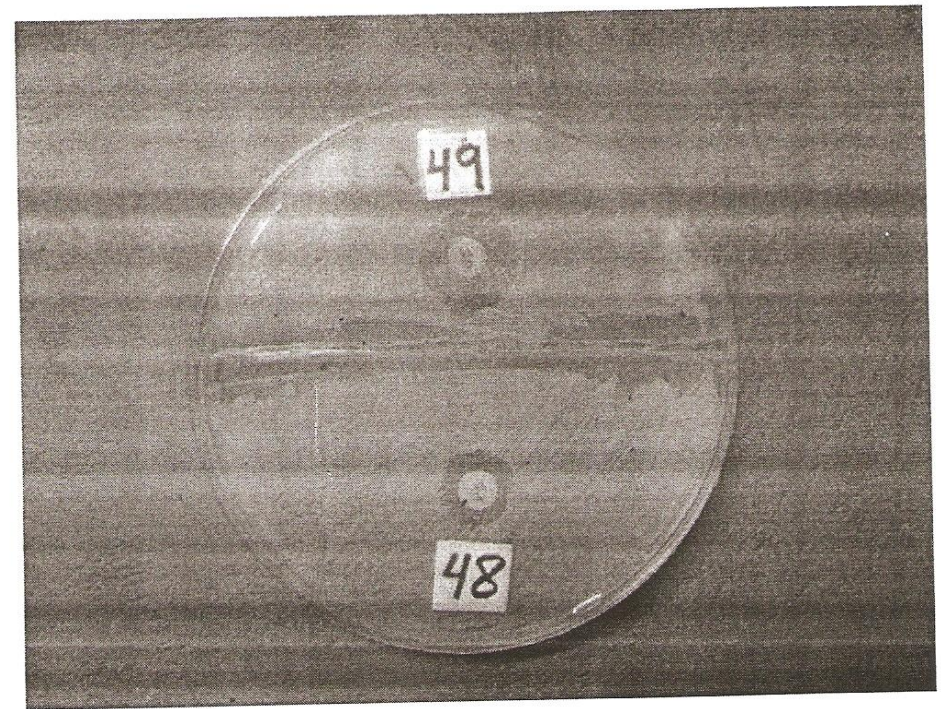

Figure (3)

The susceptibility to vancomycin:

Isolate number 49 susceptible to vancomycin, Isolate number 48 resistant to vancomycin with inhibition zone correspond to $15 \mathrm{~mm}$ and $9 \mathrm{~mm}$ respectively 
Table (4) Distribution of Patients with Methicillin susceptibility according to age

\begin{tabular}{|c||c||c||c||c||}
\hline Age year & $\begin{array}{c}\text { No. of tested } \\
\text { patient }\end{array}$ & $\begin{array}{c}\text { No. and (\%) of } \\
\text { patient +ve } \\
\text { in MSSA }\end{array}$ & $\begin{array}{c}\text { No. and (\%) of } \\
\text { patient +ve } \\
\text { in MISA }\end{array}$ & $\begin{array}{c}\text { No. and (\%) of } \\
\text { patient +ve in } \\
\text { MRSA }\end{array}$ \\
\hline \hline $5-14$ & 48 & 0 & 0 & 0 \\
\hline $15-24$ & 81 & 0 & 0 & 0 \\
\hline $25-34$ & 96 & 0 & $1(1.04)$ & $4(4-16)$ \\
\hline $35-44$ & 119 & $1(0.84)$ & $3(2.52)$ & $6(5.04)$ \\
\hline $45-54$ & 140 & 0 & $5(3.57)$ & $9(6.42)$ \\
\hline $55-65$ & 63 & $2(3.17)$ & $2(3.17)$ & $6(9.52)$ \\
\hline Total & 547 & $3(2.97)$ & $11(10.89)$ & $25(24.75)$ \\
\hline \hline
\end{tabular}

Table (5) Distribution of Patients with Methicillin resistance staphylococci (CONS)

\begin{tabular}{|c||c||c||}
\hline \multicolumn{1}{|c||}{ Age year } & No. of tested patient & No. and ( $\%$ of patient +ve MRS in \\
& & VICONS \\
\hline \hline $5-14$ & 48 & 0 \\
\hline $15-24$ & 81 & 0 \\
\hline $25-34$ & 96 & $1(0.84)$ \\
\hline $35-44$ & 119 & $3(2.14)$ \\
\hline $45-54$ & 140 & $3(4.76)$ \\
\hline $55-65$ & 63 & $7(6.93)$ \\
\hline Total & 547 & 0 \\
\hline \hline
\end{tabular}


Table (6) Frequency of bacterial isolates in patients UTI

\begin{tabular}{|l||c||c||}
\hline \multicolumn{1}{|c||}{ Other bacteria } & No. of isolates & Relative frequency (\%) \\
\hline \hline Escherichia coli & 21 & 38.18 \\
\hline Pseudomonas aeruginosa & 16 & 29.09 \\
\hline Klebsiella pneumoniae & 12 & 21.81 \\
\hline Entercoccus faecalis & 6 & 10.90 \\
\hline Total & 55 & 99.98 \\
\hline
\end{tabular}

\section{$\underline{\text { Discussion }}$}

Methicillin - Resistant Staphylococcus aureus (MRSA) has become a major epidemiological and clinical problem over the last decades [21-23]. These strains have spread worldwide, causing nosocomial and more recently community - based infections [24]. This has led to the overuse of glycopeptides, and to the emergence of Vancomycin -resistant S.aureus [25]. Isolates of Vancomycin resistant S.aureus have emerged in many parts of the world. These isolates appear to achieve clinically relevant levels of resistance to Vancomycin that leads to treatment failure. With VRSA-MRSA infection, the wrong of frequent use of Vancomycin, Methicillin causes the Staphylococcus bacteria to become resistant [26].

As strains of S.aureus with reduced susceptibility continue to emerge and evolve, perhaps to full resistance, there is a clinical need to fully characterize them and conduct well-designed research and epidemiological studies.

Concern over development of VRSA emanates from the newly widespread occurrence of
Vancomycin resistant strains of enterococci (VRE) [27].

In this study, 101 patients (adults of non -adults) from 547 $(18.46 \%)$ were proved to be infected with UTI. Males were 32 patients (14.95\%) while, female's patients were 69(20.72\%), Table (2). We know in female sex short urethra allowing bacteria quick access to the bladder, also, females urethra opening is near sources of bacteria from the anus and vagina these play a role in the migration of pathogens and lead to UTI [5, 28]. Anyhow, our results were consistent with workers [10, 24] observation.

Concerning Table (3), the highest isolation rate of S.aureus (VRSA, VISA and VSSA) tend to be frequently distributed in ages above 50 years, which correspond in patient's ( +ve VRSA) to $2.14 \%, 7.93 \%$ while, in patient's (+ve VISA \& +ve VSSA) were represented $2.14 \%, 4.76 \%, 4.28 \%$ and $12.69 \%$ respectively.

Hakim et.al [29] found that, out of 850 isolates (S.aureus), 250 were MRSA, of which $22 \%$ were resistant to $4 \mathrm{mcg}$ and $13.2 \%$ to $30 \mathrm{mcg}$ vancomycin. 
Also, $13 \%$ of the strains were intermediates (VISA), this result was somewhat in accordance with the results of present study.

The current study shows that, the highest isolation rate of infection with S.aureus (+ve) in MRSA correlated with patients in age groups 45-54 and 55-65 years which correspond to $6.42 \%$, $9.52 \%$ respectively and the total isolation rate of infection by S.aureus (MRSA) was $24.75 \%$ in 25 cases, Table (4).

In study of Lin et.al [30] detected that, infections cases by Staphylococcus aureus ( MRSA) particularly nosocomial infection in a Medical Center , 1990 correspond to 53 $(66.3 \%)$. Those findings were, to some extent, in agreement with the results of current study only concerning with the isolation rate of MRSA.

On the other hand, in this study, the occurrence of infection with MR Staphylococci (CONS) correspond to $(4.76 \%)$ in 7 cases which, associated with patients in age group 55-65 years, Table (5).

However, a few recent studies proposed that significance of some CONS species as uropathogens may have been somewhat under estimated [31], a result was somewhat in consistence with the results of present study.

Furthermore, the current search shows, presence of several bacterial species other than S.aureus in 55 infected people (patient's UTI), as appeared in Table (6).

They consisted of E.coli $(38.18 \%)$ which was the most common bacteria, followed by P.aeruginosa (29.09\%), K. pneumoniae $(21.81 \%)$ and
E.faecalis (10.90\%). However, the total of bacterial isolates in patient's UTI was $99.98 \%$.

Nasseab [32] study, revealed, the most common bacteria caused NUTI was E.coli (26.47\%) followed by P.aeruginosa $(23.53 \%)$ and frequency of total bacterial isolates in patient's NUTI was $100 \%$, this result was somewhat in accordance with the our findings.

In Conclusion: I believe that the current vancomycin staphylococci in hospital are alarming situation to the clinicians and the emergence of Staphylococcus aureus with reduced susceptibility to vancomycin threatens to return us to the era that preceded the development of antibiotics.

\section{References}

1- Gleckman RA.Urinary tract infection.Clin Geriatr Med, 1992. 8: 793-803.

2- Sobel JD, Kaye D. Urinary tract infections. In: Principles and practice of infectious Disease. Edited by Mandell ; Douglas and Bennett. $3^{\text {rd }}$ ed. P. 582-609. Philadelphia, U.S.A, 1989.

3- Kunin CM. Urinary tract infections in females. Clin Infect Dis, 1991, 18:112.

4- Stamm WE. Urinary tract infections and pylonephritis. In: Harrison's Principles of Internal Medicine, 1996. Volume 2.

5- Spiegd A. Urinary tract infection in adults. National Kidney and Urologic Diseases information clearing house (NIDDK). (Internet, Urinary Tract Infection in Adults), 2001.

6- Boscia JA, Kaye D.Asymptomatic bacteriuria in the elderly. Infect Dis Clin. North Am, 1997, 1893 1905. 
7- Gabriel MM et.al. Uncovering urinary tract infections. P. 1-11. Georgia, U.S.A, 1997.

8- The Merck Manual of Diagnosis and Therapy. Section 17. Genitourinary Disorders. Chapter 227. Urinary Tract Infections, 2001 (Internet).

9- Cowan ST. Cowan \& Steels manual for identification medical bacteria. $2^{\text {nd }}$. Cambirdge University Press,Cambirdge,London, 1974.

10- Holt JG et.al. Bergay's Manual of Determinative Bacteriology. $9^{\text {th }}$ ed. William and Wilkins, Baltimore, 1994.

11- Collee JG et.al. Tests for the identification of bacteria. In: Makie and MacCarteny Practical Medical Microbiology. Edited by Collee JG, Fraser AG, Marmion BP and Simmons A. $14^{\text {th }}$ ed. P.131-149. Churchill Livingstone, London, 1996.

12- Hiramatsu, K. Vacomycin resistance in Staphylococci. Drug. Resist. Update, 1991, 1: 135-150.

13- Kuroda M et.al. Whole genome sequencing of Methicillin resistance Staphylococcus aureus. Lancet, 2001, 357: 1225-1240.

14- Bauer A W et.al. Antibiotic susceptibility testing by standardized single disk method. Am J Clin Path, 1966, 45: 493496.

15- Jarvis W R, Martone W J. Predominate pathogens in hospital. Infect $\mathbf{J}$ Antimicrob Chemother, 1992, 29:19.

16- Hiramatsu K et.al. Methicillin - resistant Staphylococcus aureus Clinical strain with reduced vancomycin susceptibility. J Antimicrob Chemother, 1997. (In Press).

17- Cowan S T, Steel K J. Manual for the identification of Medical Bacteria. $2^{\text {nd }}$ ed. Cambridge University press. Cambridge, London, 1975, PP: 170, 174, 180.
18 - World Health Organization (WHO) Guide, 1991.

19- Cruickshank $\mathrm{R}$ et.al. Medical Microbiology. Vol. 2.12 $2^{\text {th }}$ ed. Churchill Livingstone. Edinburgh, London, 1975, PP: 171,175, 178,181 .

20- Weckbach L S, Langlois B E. Classification by numerical taxonomy of Staphylococci isolated from the bovine udder. $\mathbf{J}$ Milk. Food Technol, 1976, 39: 246-249.

21-Mathur SK et al. Prevalence of methicillin resistant Staphylococcus aureus (MRSA) in tertiary care hospital.Indian.J.Med.Microbiol,1 994,12:96-101.

22-Madani TA.Epidemiology and clinical features of methicillin resistant S.aureus in University Hospital.Jeddah,Saudi

Arabia,Canadian,J.Infectious Disease, 2002,13(4): 245-250.

23- Kotilainen $\mathrm{P}$ et.al. Elimination of epidemic methicillin resistant S.aureus from a University Hospital and district institutions. Finland, CDC, 2003, 9(2): 220233.

24- Chambers H.F. The changing epidemiology of Staphylococcus aureus? Emerg, Infect, Did, 2001, 7: $178-82$.

25- Centers for Disease Control and prevention (CDC).Staphylococcus aureus resistant to vancomycin. United States, 2002, Morb, Mortal, Wkly, 51: 565 -7.

26- Srinivasan A et.al. Vancomycin resistance in Staphylococci. Clin, Microbiol, 2002, 15(3): 430-438.

27- Denis $\mathrm{O}$ et.al. Emergence of vancomycin - Intermediate Staphylococcus aureus in a Belgian hospital. Microbiological and Clinical features, $\mathbf{J}$ Antimicrob, Chemother, 2002, 50: 383-391. 
28- Weir M, Brien J. Adolescent Urinary Tract Infections. Adolesc, Med, 2000, 11: 293-313.

29- Hakim ST et.al. Vancomycin sensitivity of Staphylococcus aureus isolates from Hospital patients in KARA chi, PAKISTAN. Department of Microbiology, Jinnah University for woman, Nazimabed, Karachi74600, Pakistan, 2007, P. 1-6.

30- Lin K S et.al. A Survey of S.aureus nosocomial infection among hospitalized patients in a Medical Center. Nosocomial Infection
Control Committee, Tri - Service Hospital , Department of Clinic Pathology , Tri-Service General Hospital , 1995, P.1-8.

31- Srdjan S et.al. Isolation of members of the Staphylococcus sciuri group from urine and their relationship to urinary tract infections. Journal of Clinical Microbiology, 2003, P. 5262- 5264, Vol, 41, No.11.

32- Nasseab L A N. Bacteria causing nosocomial urinary tract infection in adults. B.Sc. thesis, College of Science, Basrah University, 2002.

\section{LIST OF ABBREVIATIONS}

\begin{tabular}{|l|l||}
\hline \multicolumn{1}{|c|}{ Breviary } & \multicolumn{1}{|c|}{ Name } \\
\hline \hline 1-AROs & Antibiotic Resistant Organisms \\
2-MRSA & Methicillin Resistant Staphylococcus aureus \\
3-VRSA & Vancomycin Resistant Staphylococcus aureus \\
4-COPS & Coagulase Positive Staphylococci \\
5-CONS & Coagulase Negative Staphylococci \\
6-VISA & Vancomycin Intermediate Staphylococcus aureus \\
7-VSSA & Vancomycin Susceptible Staphylococcus aureus \\
8-MISA & Methicillin Intermediate Staphylococcus aureus \\
9-MSSA & Methicillin Susceptible Staphylococcus aureus \\
10-MRCONS & Methicillin Resistant Coagulase Negative Staphylococcus \\
11-VICONS & Vancomycin Intermediate Coagulase Negative Staphylococcus \\
12-UTI & Urinary Tract Infection \\
13-NA & Nutrient Agar \\
14-MA & MacConkey Agar \\
15-BA & Blood agar \\
16-MSA & Mannitol Salt Agar \\
. . .... & .. ... ... . .
\end{tabular}




\title{
عزل وتثخيص جرثومة العنقوديات الذهبية Staphylococcus aureus المقاومة للفانكومايسين والمشلين من المرضى المراجعين لمستشفى الثفاء العام في مدينة البصرة
}

\author{
ريهام محمد مصطقى الموسوي \\ كلية العلوم ـ قسم علوم الحياة - جامعة البصرة- العراق
}

\section{الخلاصة}

عمل البحث على عزل وتتخيص S.aureus المقاومة للفانكومايسيين و المشلين على 547 عينة من المــر اجعين (راشــدين و غير ر اثندين) للعيادة الاستشارية الخارجية في مسنتفى الثفاء العام في مدينة البصرة للفترة من تشرين الأول 2007 إلى آذار

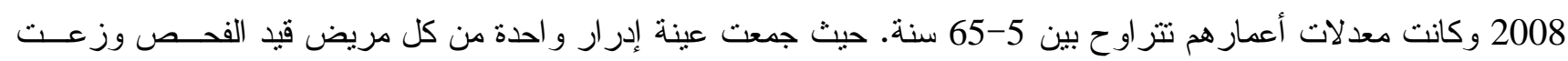
بطريقة التخطيط على الأوساط الزرعية المدعمة والانتقائية (التقريقية) لان اغلب ممرضات الجهاز البولي الثائعة و الممرضــات

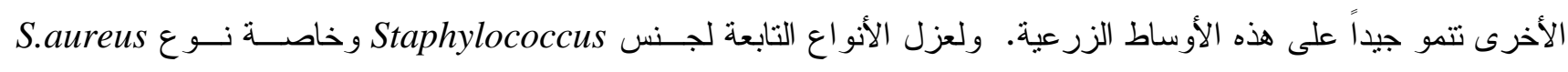

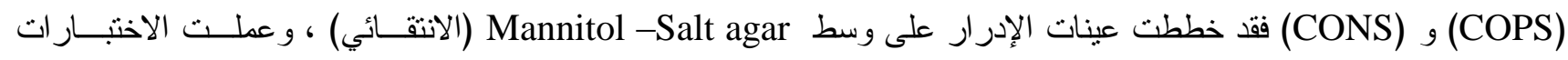

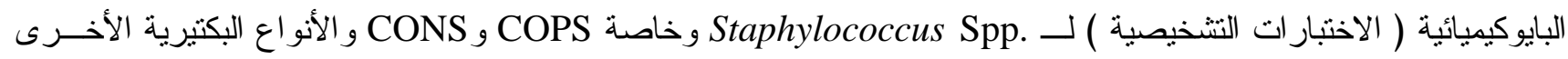

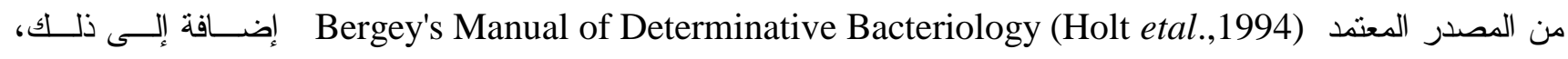

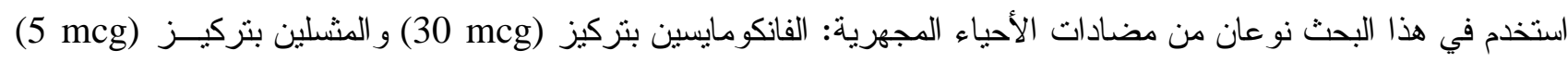
لاجر اء اختبار الحساسية لعز لات S.aureus الجرثومية (COPSS); (CONS) . أظهرت النتائج ان المعدلات الأعلى للإصابة

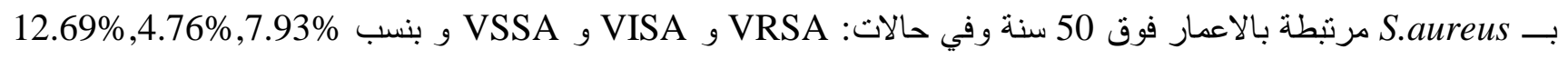

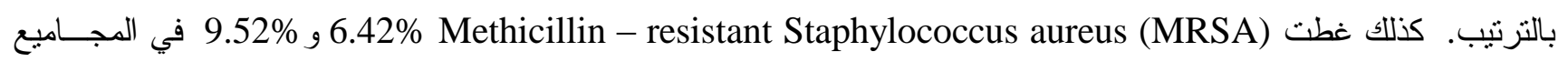

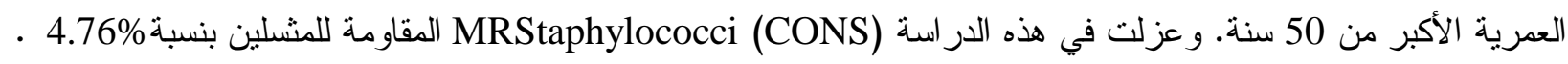

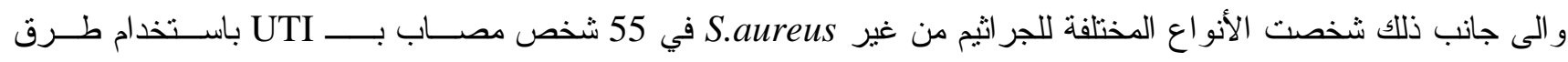

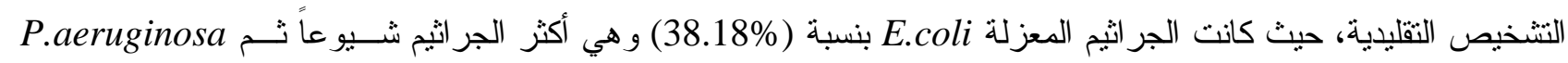
.(10.90\%) E.faecalis و(21.81\%) K.pneumoniae g(29.9\%) 